\title{
Neuroprotective effects of ginseng pectin through the activation of ERK/MAPK and Akt survival signaling pathways
}

\author{
YUYING FAN $^{1}$, CHENGXIN SUN $^{1}$, XIAOGE GAO $^{1}$, FANG WANG $^{1}$, \\ XINZHI LI ${ }^{1}$, RAJAB M. KASSIM ${ }^{1}$, GUIHUA TAI ${ }^{1,2}$ and YIFA ZHOU ${ }^{1}$ \\ ${ }^{1}$ School of Life Sciences, Northeast Normal University, Changchun, Jilin 130024; \\ ${ }^{2}$ State Key Laboratory of Natural and Biomimetic Drugs, Peking University, Beijing 100191, P.R. China
}

Received November 18, 2011; Accepted February 15, 2012

DOI: $10.3892 / \mathrm{mmr} .2012 .811$

\begin{abstract}
In this study, we investigated the neuroprotective activities of ginseng pectin (GP) against hydrogen peroxide $\left(\mathrm{H}_{2} \mathrm{O}_{2}\right)$-induced neuronal toxicity in different neuronal cells. GP selectively attenuated $\mathrm{H}_{2} \mathrm{O}_{2}$-induced damage up to $26 \%$ in primary cortical neuron cells and human glioblastoma U87 cells. Following $\mathrm{H}_{2} \mathrm{O}_{2}$ exposure, DAPI staining and neuron-specific $\beta$-tubulin antibody probing indicated that GP maintained cell integrity and decreased nuclei condensation. Data from western blot analysis revealed that pre-treatment with GP increased the phosphorylation of both the extracellular signal-regulated kinases 1 and 2 (ERK1/2) and Akt in cortical neuron cells. However, the phosphorylation of ERK1/2 was increased, but that of Akt was decreased in U87 cells. These results suggest that the protective effects of GP against $\mathrm{H}_{2} \mathrm{O}_{2}$-induced apoptosis may be due to the activation of the phosphorylation of ERK1/2 and Akt; however, the mechanisms involved differ depending on the cell line. This neuroprotective property indicates that GP could serve as a potential therapeutic agent for neurodegenerative diseases.
\end{abstract}

\section{Introduction}

Oxidative stress is a prominent factor of cell death in glutamate- or hydrogen peroxide $\left(\mathrm{H}_{2} \mathrm{O}_{2}\right)$-induced cytotoxicity and neurodegenerative diseases, such as Alzheimer's disease (AD), atherosclerosis, Parkinson's disease and stroke $(1,2)$. Oxidative stress-induced damage is mediated by reactive oxygen species (ROS), including $\mathrm{H}_{2} \mathrm{O}_{2}$, superoxide and hydroxyl radicals, which are generated as products of normal and aberrant metabolic processes that utilize molecular oxygen. ROS attacks proteins, deoxyribonucleic acids and lipid membranes, thereby disrupting cellular function and integrity $(3,4) . \mathrm{H}_{2} \mathrm{O}_{2}$ induces

Correspondence to: Dr Yifa Zhou, School of Life Sciences, Northeast Normal University, 5268 Renmin Street, Changchun, Jilin 130024, P.R. China

E-mail: zhouyf383@nenu.edu.cn

Key words: ginseng pectin, neuronal protection, oxidative stress, ERK/MAPK signaling pathway, Akt signaling pathway apoptosis in many different cell types, and this effect can be blocked by the addition of anti-oxidants (5-7).

Mitogen-activated protein kinases (MAPKs) respond to extracellular stimuli, and regulate various cellular activities, such as differentiation, proliferation, survival and apoptosis. Extracellular signal-regulated kinases 1 and 2 (ERK1/2) are known as classical MAP kinases, which were activated in response to stress signals. A previous study revealed that abnormal levels of phosphorylated ERK1/2/MAPK in the brains of AD patients are associated with oxidative stress (8). Alternatively, the modulation of signaling through the serine/ threonine kinase, Akt/protein kinase B (PKB), one of the main downstream effectors of phosphatidylinositol 3-kinase (PI-3K) and a pivotal kinase in neuronal survival, may also play an important role (9-11).

Panax ginseng C.A. Meyer (ginseng) is a medicinal plant with a wide range of therapeutic benefits and has many active chemical components, such as ginsenosides, ginseng polysaccharides and ginseng peptides $(12,13)$. Ginsenoside $\mathrm{Rb} 1$ is the main neuroprotective molecule of ginseng. It facilitates cholinergic function and increases synaptophysin levels in the hippocampus, potentiates the nerve growth factor (NGF)-mediated neurite outgrowth (14-16), reduces oxidative stress caused by hydrogen peroxide (17), and promotes neurite length and number after exposure to glutamate or hydrogen peroxide (18).

Ginseng polysaccharides contain starch-like glucans and pectins. Ginseng pectins (GPs) are the main active compounds with various bioactivities. They impair cell migration through decreasing cell adhesion and cell spreading $(19,20)$; have anti-fatigue activity via reducing glucose and glutathione peroxidase and increase creatine phosphokinase, lactic dehydrogenase and malondialdehyde levels (21); inhibit human colon cancer HT-29 cell proliferation accompanied by the activation of caspase-3; and induce cell cycle arrest in the $\mathrm{G} 2 / \mathrm{M}$ phase (22). In this study, we report the neuroprotective effects of GP against $\mathrm{H}_{2} \mathrm{O}_{2}$-induced damage and the possible mechanisms involved. The results may be useful for the development of drugs from GP to treat neurodegenerative diseases.

\section{Materials and methods}

Materials. Ginsenoside Rb1 (>98\% pure) was purchased from the Chinese Inspection and Identification Institute of 
Biological Products and Medicine (Beijing, China). Neuro 2A (mouse neuroblastoma) cells, U87 (human glioblastoma) cells and SH-SY5Y (human neuroblastoma) cells were all obtained from the American Type Culture Collection (ATCC); 3-(4, 5-dimethylthiazol-2-yl)-5-(3-carboxymethoxyphenyl)2-(4-sulfophenyl)-2H-tetrazolium (MTS) was from Promega (G3581); the mouse monoclonal, Tuj, antibody was from Neuromics (MO15013); and monoclonal anti- $\gamma$-tubulin antibody was from Sigma (T5326). p44/42 MAP kinase (3A7) mouse monoclonal antibody (9107), phospho-p44/42 MAPK (Thr202/Tyr204) antibody (9101S), Akt antibody (9272) and phospho-Akt (Thr308) antibody (9275S) were all from Cell Signaling Technology. All other reagents were of analytical grade or better.

Preparation of ginseng pectins. Ginseng polysaccharides were dissolved in water and digested with $\alpha$-amylase (E.C. 3.2.1.1) at $37^{\circ} \mathrm{C}$ for $16 \mathrm{~h}$. The enzyme was inactivated by boiling for $10 \mathrm{~min}$ before being removed by centrifugation. To remove proteins, the resulting supernatant was further treated with Sevag reagent (n-butanol:chloroform 1:4), and then precipitated with $75 \%$ ethanol to gain the GP. After dialysis against distilled water followed by lyophilization, pure GPs were obtained.

Cell culture. Neuro 2A, U87 and SH-SY5Y cells were obtained from the ATCC. Neuro 2A cells were cultured in DMEM medium, and the others in RPMI-1640 medium. All media were supplemented with $10 \%$ fetal calf serum, $100 \mathrm{U} / \mathrm{ml}$ penicillin, $100 \mu \mathrm{g} / \mathrm{ml}$ streptomycin and $10 \mathrm{mM} \mathrm{HEPES}$ at $37^{\circ} \mathrm{C}$ in a humidified atmosphere of $5 \% \mathrm{CO}_{2}$.

Preparation of mouse cortical neuron cells. Pregnant animals were cared and handled in accordance with the guidelines of Northeast Normal University for the use of laboratory animals. Pregnant C57BL6/J mice (15th day of gestation) were sacrificed with sodium pentobarbital $(80 \mathrm{mg} / \mathrm{kg})$, the uteri were dissected and the embryos were carefully removed and transferred to a culture dish with harvest medium (Hank's medium with $1 \%$ HEPES buffer and $1 \%$ antibiotics). The brains were dissected, the cortex was excised and primary cultures were prepared as follows: briefly, the cortex was removed from the hemisphere and minced into small pieces. Cells were disaggregated in Hank's medium supplemented with $2.5 \%$ trypsin and $1 \%$ DNase and incubated for $15 \mathrm{~min}$ at $37^{\circ} \mathrm{C}$. After centrifugation at $100 \mathrm{rpm}$ for $5 \mathrm{~min}$, the cell pellet was resuspended with plating medium (MEM medium with $2.5 \% \mathrm{NaHCO}_{3}, 1 \%$ pyruvic acid, $20 \%$ glucose, $10 \% \mathrm{FBS}$ and $1 \%$ antibiotics). Cell density was adjusted to $4 \times 10^{4}$ cells $/ \mathrm{cm}^{2}$ in $65-\mathrm{mm}$ dishes coated with $40 \mu \mathrm{g} / \mathrm{ml}$ of poly-D-lysine. The following day, the maintaining medium (neurobasal medium with 2\% B-27 and 5\% L-glutamine) was replaced with plating medium and cells were cultured for 5-7 days.

Oxidative stress assay. Stock solution of ginsenoside Rb1 $(100 \mu \mathrm{M})$ and GP $(5 \mathrm{mg} / \mathrm{ml})$ in medium was prepared. Cells were pre-treated either with $\mathrm{Rb} 1$ at final concentration of 0 , 20,40 and $80 \mu \mathrm{M}$, or GP at $0.0,0.01,0.05$ and $0.5 \mathrm{mg} / \mathrm{ml}$ for $1 \mathrm{~h}$ at $37^{\circ} \mathrm{C}$ in a humidified atmosphere of $5 \% \mathrm{CO}_{2}$. Removing $\mathrm{Rb} 1$ or GP, cells were exposed to $100 \mu \mathrm{M}$ of $\mathrm{H}_{2} \mathrm{O}_{2}$ for $30 \mathrm{~min}$ at $37^{\circ} \mathrm{C}$. After rinsing off $\mathrm{H}_{2} \mathrm{O}_{2}$, the cells were maintained in the same concentration of Rb1 or GP for 24, 48, 72 and $96 \mathrm{~h}$. Control cells were kept in parallel with medium alone. The cell viability was determined by MTS assay. MTS reagent $(100 \mu \mathrm{l})$ was added to each well and cells were incubated at $37^{\circ} \mathrm{C}$ in a humidified atmosphere of $5 \% \mathrm{CO}_{2}$ for $30 \mathrm{~min}$. The $\mathrm{OD}_{490}$ and $\mathrm{OD}_{690}$ values were measured by an automated spectrophotometric plate reader. The value of $\mathrm{OD}_{490}$ subtracted from $\mathrm{OD}_{690}$ represented the cell survival rate.

Morphology assay. On the 5th day of cortical neuron cell culture, cells were fixed with $4 \%$ paraformaldehyde/PBS ( $\mathrm{pH}$ 7.0) at room temperature for $20 \mathrm{~min}$. They were then washed with PBS and $100 \mathrm{mM} \mathrm{NH}_{4} \mathrm{Cl} / \mathrm{PBS}$. The cells were permeabilized with $0.025 \%$ saponin/PBS at room temperature for $10 \mathrm{~min}$, with no shaking. Incubated monoclonal Tuj antibody (neuron-specific class III $\beta$-tubilin) was diluted with blocking buffer (2\%BSA/5\%FBS/PBS-filtered saponin at 2:1) at 1:100 at room temperature for $60 \mathrm{~min}$. The cells were then washed with PBS. The cells were incubated with FITC-goat anti mouse $\operatorname{IgG}(1: 100)$, at room temperature for $30 \mathrm{~min}$, in the dark. The cells were washed with PBS again. The slides were mounted with $2.5 \mu \mathrm{l}$ of vecta shield and sealed in nail polish.

ERK/MAPK and Akt signaling pathway. For the determination of protein phosphorylation after GP or Rb1 treatment, cells were scratched off the plate in cold PBS and then lysed in lysis buffer [150 mM NaCl, 1\% TX-100, 1 mM EDTA, $1 \mathrm{mM}$ PMSF, $1 \mathrm{mM} \mathrm{Na}_{3} \mathrm{VO}_{4}$, protease inhibitor cocktail (Roche) and Tris-Cl; pH 7.4]. After centrifugation at 14,000 rpm for $5 \mathrm{~min}$, the supernatant was recovered and mixed with SDS-PAGE loading buffer. The separated proteins on the gel were transferred onto a nitrocellulose membrane and blocked in 5\% non-fat milk. Then, the membrane was incubated with primary antibodies [monoclonal anti- $\beta$-tubulin antibody 1:1,000; p44/42 MAP kinase (3A7) mouse monoclonal antibody 1:100; phospho-p44/42 MAPK 1:100; Akt antibody 1:100, phosphoAkt (Thr308) antibody 1:100] followed by HRP-conjugated secondary antibodies. Protein bands were revealed by the ECL protein detection system (GE Healthcare).

Statistical analysis. The results were expressed as the means \pm SD. Statistical analysis of the data was performed using one-way ANOVA (SPSS Statistics 17.0). Differences were considered significant when $\mathrm{p}<0.01$.

\section{Results}

Ginseng pectins preparation. GP were prepared and purified as previously described $(19,23)$. Total ginseng polysaccharides were isolated from Panax ginseng C.A. Meyer, deproteined using the Sevag method and digested using $\alpha$-amylase. Prepared GP contained $96.1 \%(\mathrm{w} / \mathrm{w})$ sugar and $45.1 \%(\mathrm{w} / \mathrm{w})$ uronic acid. GP consisted of $44.3 \%$ galacturonic acid, $20.1 \%$ galactose, $14.9 \%$ glucose, $14.1 \%$ arabinose, $3.1 \%$ rhamnose, $1.9 \%$ glucuronic acid and $1.5 \%$ mannose.

Effects of hydrogen peroxide on different neuronal cells. The oxidative stress effects of hydrogen peroxide on different neuronal cells was evaluated by the MTS method. The cells were incubated with optimal medium for $48 \mathrm{~h}$, the medium was 
A

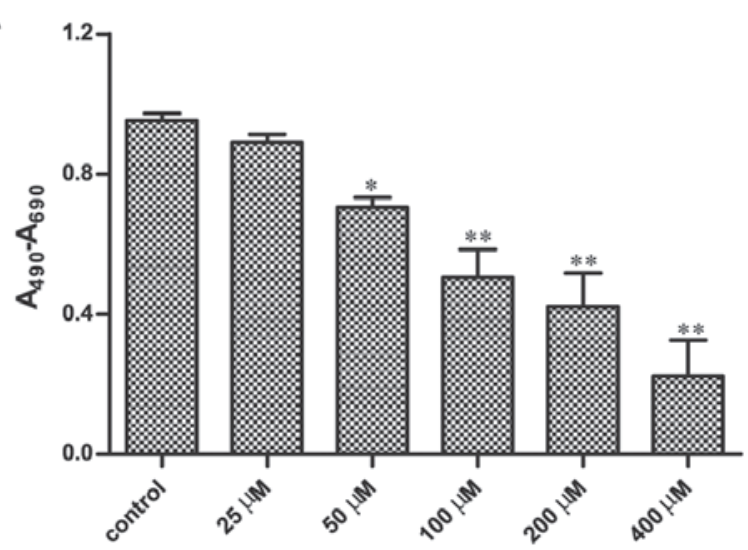

C

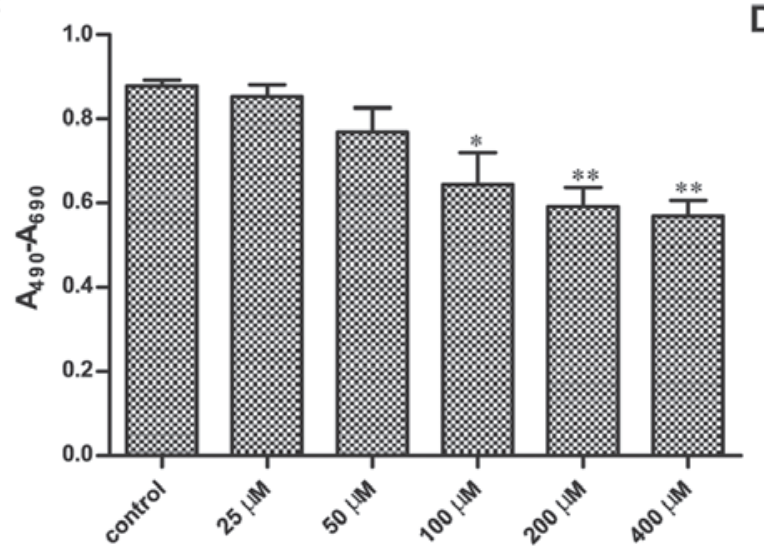

B

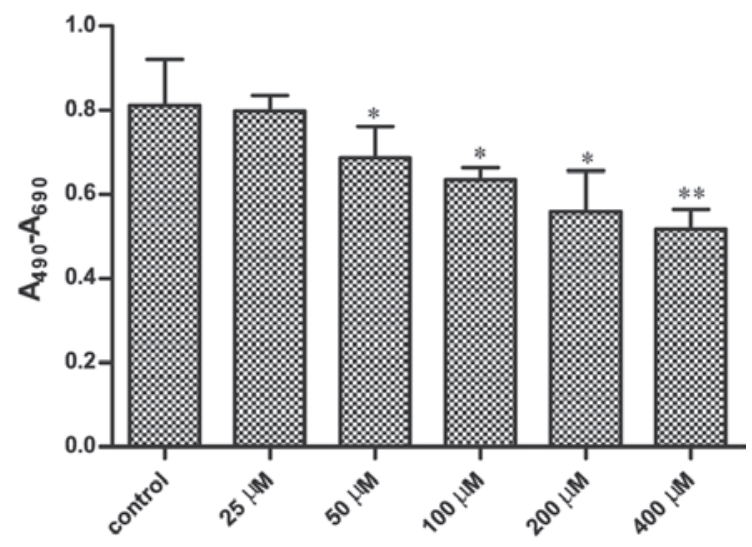

D

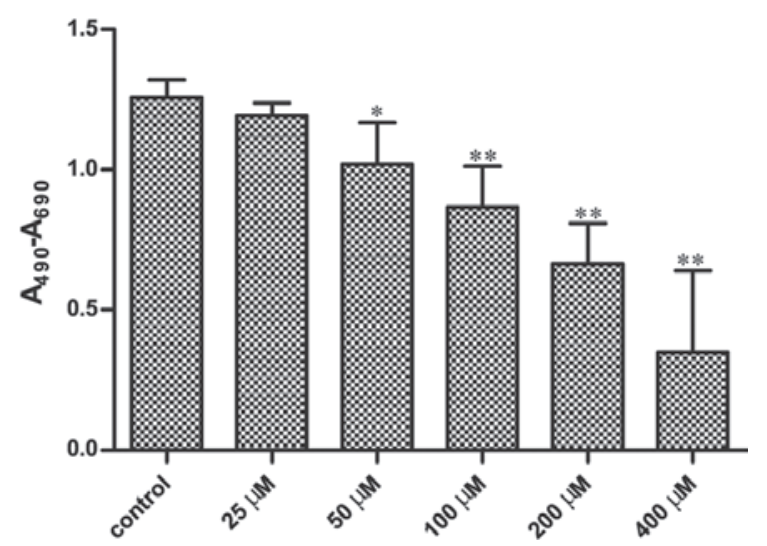

Figure 1. Effects of hydrogen peroxide $\left(\mathrm{H}_{2} \mathrm{O}_{2}\right)$ on different neuronal cells. $\mathrm{H}_{2} \mathrm{O}_{2}$ activity was measured by MTS assay. (A) Cortical neuron cells, (B) Neuro 2A cells, (C) SH-SY5Y cells and (D) U87 cells, at 30 min after exposure to various concentrations of $\mathrm{H}_{2} \mathrm{O}_{2}(25-400 \mu \mathrm{M})$. In the control group, cells were incubated with medium alone. Each bar represents the means \pm SD of 3 experiments. ${ }^{*} \mathrm{p}<0.01,{ }^{* *} \mathrm{p}<0.001$.

discarded and then cells were treated with different concentrations of hydrogen peroxide for $30 \mathrm{~min}$. The effect of hydrogen peroxide on the cells is shown in Fig. 1. Exposing neuronal cells to hydrogen peroxide for 30 min caused the cell viability to decrease in a dose-dependent manner. The cortical neuron cells and U87 cells were more sensitive to oxidative injury, the survival percentages with $400 \mu \mathrm{M} \mathrm{H}_{2} \mathrm{O}_{2}$ treatment were merely 24 and $28 \%$ (Fig. 1A and D), and the medium effect was at $100 \mu \mathrm{M}$. However, the survival percentage of Neuro $2 \mathrm{~A}$ cells and $\mathrm{SH}-\mathrm{SY} 5 \mathrm{Y}$ cells with $400 \mu \mathrm{M}$ of $\mathrm{H}_{2} \mathrm{O}_{2}$ treatment was 64 and 65\%, respectively (Fig. 1B and C). Therefore, in the neuronal protective activity assay, the protective effects of both ginsenoside Rb1 and GPs on the neuronal cells were tested with treatment of $100 \mu \mathrm{M} \mathrm{H}_{2} \mathrm{O}_{2}$ in cortical neuron and U87 cells, but $400 \mu \mathrm{M} \mathrm{H}_{2} \mathrm{O}_{2}$ in Neuro 2A and SH-SY5Y cells for $30 \mathrm{~min}$.

GP protects neuronal cells from hydrogen peroxide-induced cell death. The neuronal protective effect of GP against hydrogen peroxide-induced cell death was examined in different neuronal cells. The cells were pre-treated with either $40 \mu \mathrm{M}$ of $\mathrm{Rb} 1$ or different concentrations of GP $(0.01,0.05$ and $0.5 \mathrm{mg} / \mathrm{ml}$ ) for $24 \mathrm{~h}$. GPs and Rb1 were found to protect neuronal cells from hydrogen peroxide-induced cell death, but this effect was not related to concentration (Fig. 2). GP $(0.05 \mathrm{mg} / \mathrm{ml})$, which increased cell viability after exposure to hydrogen peroxide, did not affect cell proliferation compared to the control cells. The exposure of the cortical neuron cells for $30 \mathrm{~min}$ to $100 \mu \mathrm{M}$ of hydrogen peroxide caused a $40 \%$ decrease in cell viability. However, there was only a $14 \%$ decrease in cell viability in the cells pre-treated with $0.05 \mathrm{mg} /$ $\mathrm{ml}$ of GP, meaning that GP recovered the cell viability by $26 \%$. The protective effect of GP was similar to that of the positive control, Rb1, in the cortical neuron cells (Fig. 2A). After exposure to $400 \mu \mathrm{M}$ of hydrogen peroxide, Neuro $2 \mathrm{~A}$ and SH-SY5Y cell viabilities showed a significant decrease, 34 and $34 \%$, respectively. However, pre-treatment with $0.05 \mathrm{mg} /$ $\mathrm{ml}$ of GP resulted in a decrease of 31 and $26 \%$, suggesting that GP has little protective effect on hydrogen peroxide-induced toxicity in these two cell lines (Fig. 2B and C). As for the U87 neuroblastoma cells, $0.05 \mathrm{mg} / \mathrm{ml}$ of GP dominantly attenuated cell viability by $25 \%$ after $100 \mu \mathrm{M}$ of hydrogen peroxideinduced cell injury (Fig. 2D).

GP protects cortical neuron cell neurites from degeneration. Maintaining the integrity of neurites was an important index of neuroprotective effects. After treatment with $100 \mu \mathrm{M}$ of $\mathrm{H}_{2} \mathrm{O}_{2}$ for $30 \mathrm{~min}$, the morphology of the cortical neuron cells was absolutely destroyed. The neurites were fragmented into many small pieces and the nuclei had shrink to one third of the untreated cell nuclei. Under treatment with $40 \mu \mathrm{M}$ of Rb1 or $0.05 \mathrm{mg} / \mathrm{ml}$ of $\mathrm{GP}$, cell morphologies were similar to the control cells, as cell neurites were long with rich branches and nuclei were large. However, after exposure to $\mathrm{H}_{2} \mathrm{O}_{2}$, a 

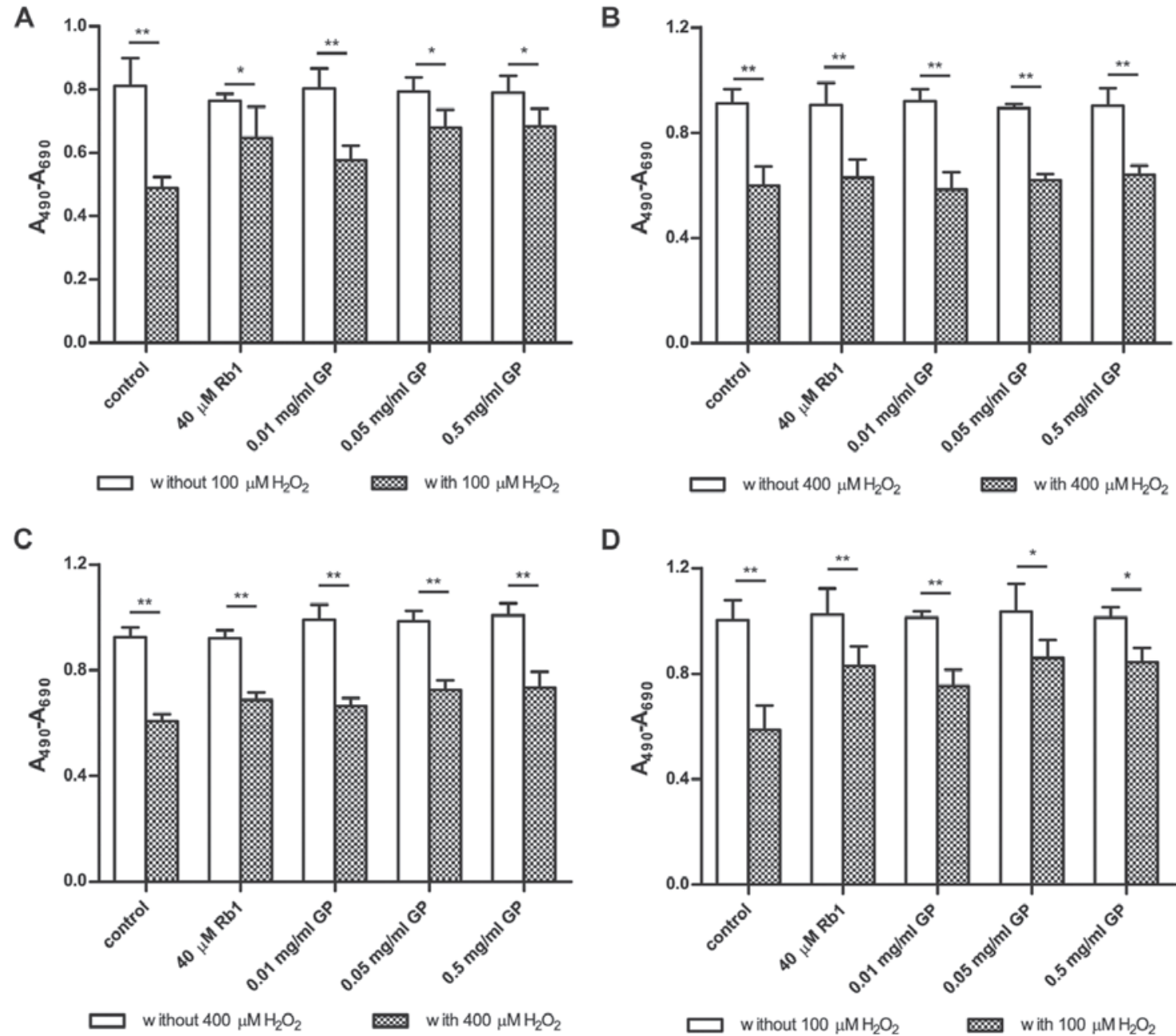

Figure 2. Effects of $\mathrm{Rb} 1$ and ginseng pectin (GP) on the protection against hydrogen peroxide $\left(\mathrm{H}_{2} \mathrm{O}_{2}\right)$-induced toxicity in neuronal cells. Cells were incubated

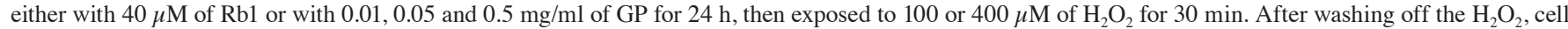
viability was determined by MTS assay. Data are the means \pm SD of 3 experiments. (A) GP significantly protected cortical neuron cells from oxidative-induced toxicity, which was similar to the effect of Rb1. (B) GP and Rb1 seemed to have little protective effect on Neuro 2A cells against oxidative-induced toxicity. (C) The neuroprotective effect of GP on SH-SY5Y cells resembled that in Neuro 2A cells. (D) GP also had neuroprotective effects in U87 cells. " $p<0.01,{ }^{* *} \mathrm{p}<0.001$.

few changes in cell morphology appeared, including certain breaks in the neurite structure. Cell morphology alteration showed that both Rb1 and GP protected cells from hydrogen peroxide-induced cell toxicity through their neuroprotective effects on neurite integrity.

GP neuroprotective effect occurs through the activation of ERK/MAPK and Akt survival signaling pathways. The effects of Rb1 and GP on ERK/MAPK and Akt signaling pathways were examined. After serum starvation overnight, the cells were treated with $40 \mu \mathrm{M}$ of $\mathrm{Rb} 1$ or $0.05 \mathrm{mg} / \mathrm{ml}$ of GP for 0 and $30 \mathrm{~min}$, then scrapped, lysed and subjected to western blot analysis using phosphorylated Akt (p-Akt) (S473), total-Akt, p-ERK1/2 and total-ERK antibodies. As shown in Fig. 4, there were some differences in protein phosphorylation status between Rb1 and GP treatment. In cortical neuron cells, both GP and Rb1 significantly increased p-ERK and p-Akt levels after $30 \mathrm{~min}$ of treatment compared to the untreated control. In the U87 cells, GP and Rb1 significantly increased p-Akt levels, but decreased p-ERK levels compared to the untreated control. However, in Neuro 2A and SH-SY5Y cells, treatment with GP and Rb1 did not alter the phosphorylated levels of Akt and ERK.

\section{Discussion}

The neuronoprotective effects of ginsenosides on the central nervous system have been reported in the literature. In this study, we report for the first time that GP selectively protects certain neuronal cell lines from hydrogen peroxide-induced toxicity. Before neuronal protective assay, we confirmed that treating cells with $\mathrm{H}_{2} \mathrm{O}_{2}$ resulted in cell viability loss in a dosedependent manner (Fig. 1). Pre-treatment with GP significantly attenuated $\mathrm{H}_{2} \mathrm{O}_{2}$-induced cell damage in cortical neuron and U87 cells (Fig. 2). The neuroprotective activity was similar to that of $\mathrm{Rb} 1$. When exposed to $\mathrm{H}_{2} \mathrm{O}_{2}$ after pre-treatment with GP or Rb1, cell morphologies under GP treatment were healthier than those under Rb1 treatment, especially the neurite length (Fig. 3). The results indicate that GP acts as a new neurotrophin.

The activation of the phosphorylation of MAPKs and Akt takes place in response to a variety of stresses, including 


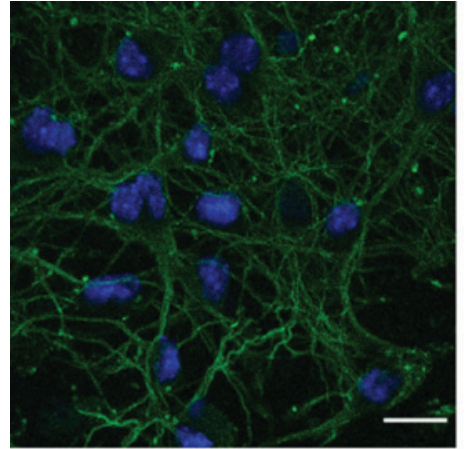

control

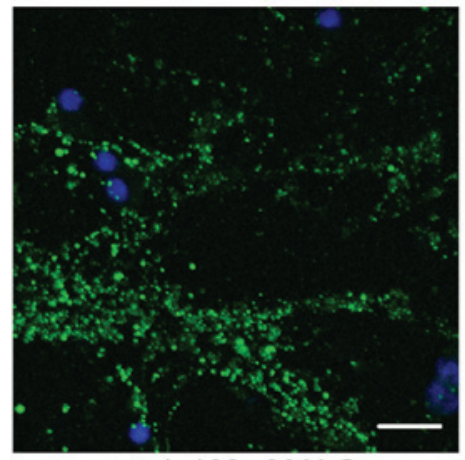

control+100 $\mu \mathrm{M} \mathrm{H}_{2} \mathrm{O}_{2}$

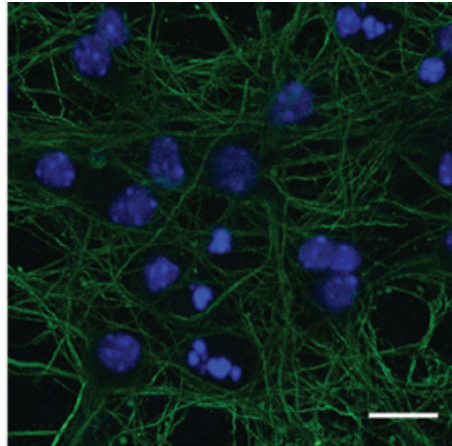

$40 \mu \mathrm{M} \mathrm{Rb} 1$

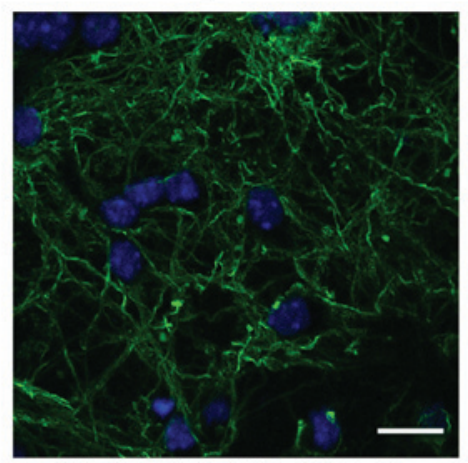

$40 \mu \mathrm{M} \mathrm{Rb} 1+100 \mu \mathrm{M} \mathrm{H}_{2} \mathrm{O}_{2}$

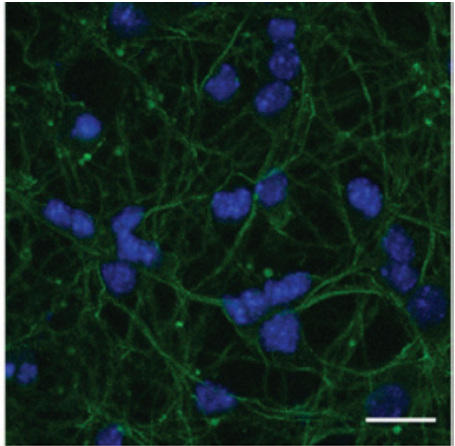

$0.05 \mathrm{mg} / \mathrm{ml} \mathrm{GP}$

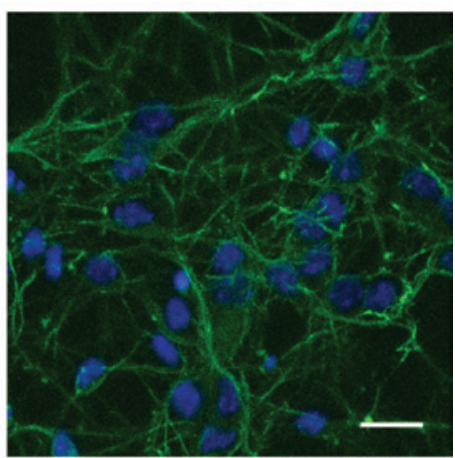

$0.05 \mathrm{mg} / \mathrm{ml} \mathrm{GP}+100 \mu \mathrm{M} \mathrm{H}_{2} \mathrm{O}_{2}$

Figure 3. Neuroprotective effects of ginseng pectin (GP) against hydrogen peroxide $\left(\mathrm{H}_{2} \mathrm{O}_{2}\right)$-induced toxicity. Cortical neuron cells were pre-treated with $40 \mu \mathrm{M}$ of $\mathrm{Rb} 1$ or $0.05 \mathrm{mg} / \mathrm{ml}$ of GP for $24 \mathrm{~h}$ (the control cells were not pre-treated), then exposed to $100 \mu \mathrm{M}$ of $\mathrm{H}_{2} \mathrm{O}_{2}$ for 30 min. Cells were processed for immunofluorescent imaging using DAPI for nucleus (blue) and monoclonal Tuj antibody for tubulin in neurites (green). Representative images were from 3 experiments under each condition. Bar, $20 \mu \mathrm{m}$.

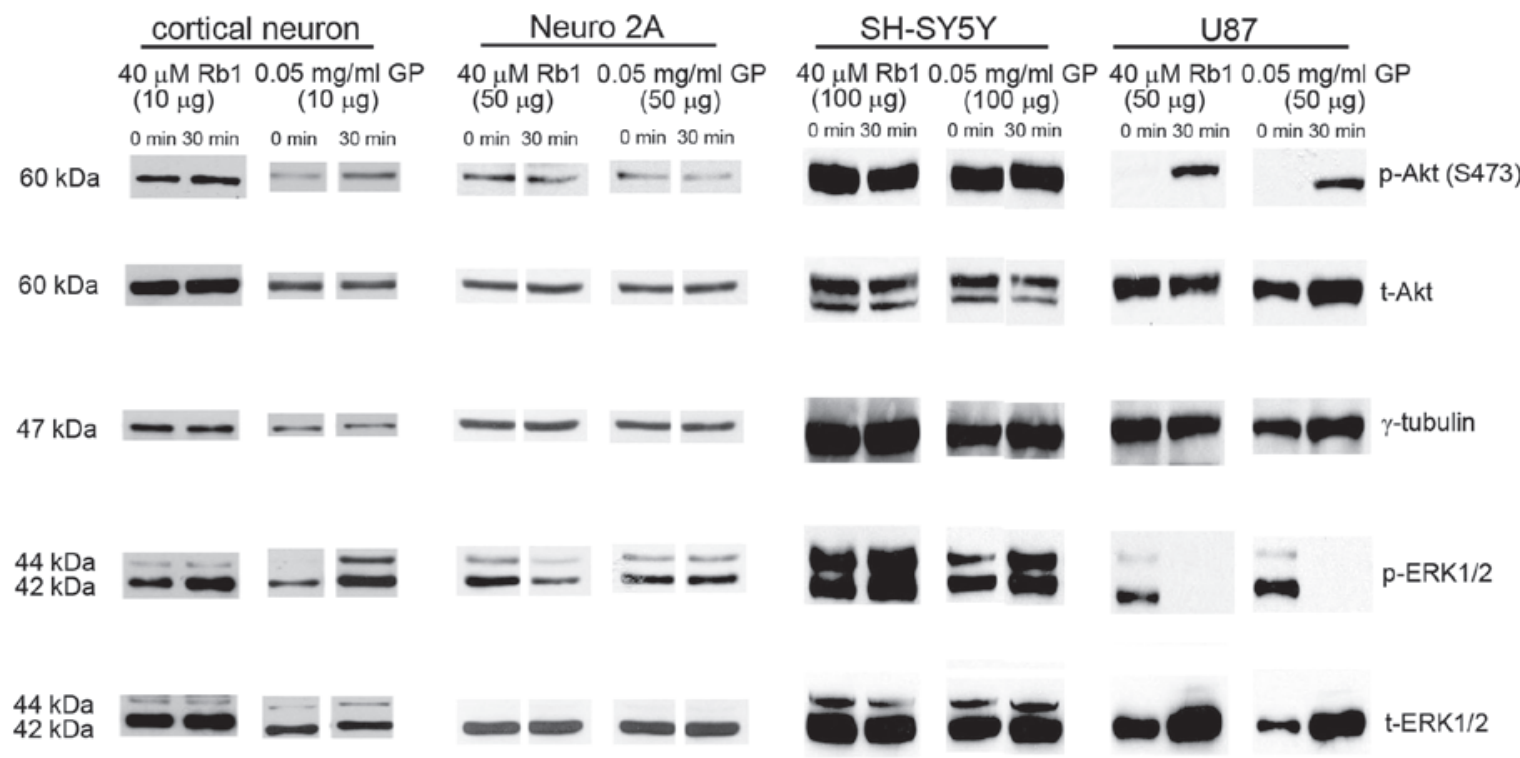

Figure 4. Rb1 and ginseng pectin (GP) activated ERK/MAPK and Akt signaling pathway in neuronal cells. After incubation for $36 \mathrm{~h}$ and serum starvation for $12 \mathrm{~h}$, neuronal cells were exposed to $40 \mu \mathrm{M}$ of $\mathrm{Rb} 1$ or $0.05 \mathrm{mg} / \mathrm{ml}$ of GP for $30 \mathrm{~min}$. The cells were lysed with lysis buffer, applied to western blotting with phosphorylated Akt (S473), total-Akt, $\gamma$-tubulin, phosphorylated ERK1/2 and total-ERK1/2 antibodies.

oxidative stress and anoxia (24). Activation of ERK/MAPK and Akt signaling pathways have been found to correlate with the ischemia protective model (25). Therefore, in this study, the pro-survival ERK/MAPK and Akt signaling pathways in different neuronal cells were examined (Fig. 4). The results showed that p-ERK1/2 and p-Akt were not altered by GP or
Rb1 treatment in Neuro 2A and SH-SY5Y cells, combined with the neuroprotective assay results suggesting that GP or Rb1 may modulate the phosphorylation of ERK/MAPK and Akt pathways to protect the $\mathrm{H}_{2} \mathrm{O}_{2}$-induced Neuro $2 \mathrm{~A}$ and SH-SY5Y cell damage. Besides, p-ERK1/2 and p-Akt were upregulated significantly under GP or Rb1 treatment in cortical 
neuron cells, upregulated p-Akt and suppressed p-ERK1/2 in U87 cell. Those neuroprotective assay results accord with the hypothesis that GP protect neuronal cells from $\mathrm{H}_{2} \mathrm{O}_{2}$-induced toxicities via pro-survival ERK/MAPK and Akt pathways.

In previous studies, ginsenoside $\mathrm{Rb} 1$ has been shown to protect neuronal cells against hydrogen peroxide-induced cell damage possibly by scavenging free radicals, inhibiting the production of nitric oxide, preventing lipid peroxidation and avoiding decrease in SOD activity. Rb1 has also been shown to promote neurite growth by increasing the expression of the nerve growth factor $(14,15,17)$. Our experimental results showed that GP and Rb1 protected neuronal cells against oxidative stress via the activation of p-ERK1/2 and p-Akt. However, the action of GP on modulating the survival signaling pathways mediated by the nerve growth factor remains to be elucidated.

Panax ginseng C.A. Meyer has been used to treat many diseases and replenish vital functions for thousands of years. In this study, GP showed similar protective effects on neuronal cells against $\mathrm{H}_{2} \mathrm{O}_{2}$-induced oxidative stress via regulating the pro-survival ERK/MAPK and Akt pathways. Moreover, GP preserved the structural integrity of neurons, suggesting that it may be a new neurotrophin. In conclusion, GP appears to be anti-oxidant without side-effects, which may eventually lead to further development of therapeutics for neurodegenerative diseases.

\section{Acknowledgements}

This study was supported by the National Natural Science Foundation of China (No. 81173605), the Doctoral Fund of Ministry of Education of China (20110043120009), the Natural Science Foundation of Jilin Province (201101013) and the Fundamental Research Funds for the Central Universities (10QNJJ012).

\section{References}

1. Andersen JK: Oxidative stress in neurodegeneration: cause or consequence? Nat Rev Neurosci 10: S18-S25, 2004.

2. Akihiko NM, George P, Gjumrakch A, et al: Oxidative damage is the earliest event in Alzheimer disease. J Neuropathol Exp Neurol 60: 759-767, 2001

3. Gardner AM, Xu FH, Fady C, et al: Apoptotic vs. nonapoptotic cytotoxicity induced by hydrogen peroxide. Free Rad Biol Med 22: 73-83, 1996.

4. Gorman AM, McGowan A, O'Neill C and Cotter T: Oxidative stress and apoptosis in neurodegeneration. J Neurol Sci 139 45-52, 1996.

5. Zhang L, Yu H, Sun Y, et al: Protective effects of salidroside on hydrogen peroxide-induced apoptosis in SH-SY5Y human neuroblastoma cells. Eur J Pharmacol 564: 18-25, 2007.
6. Xie JT, Shao ZH, Vanden Hoek TL, et al: Antioxidant effects of ginsenoside Re in cardiomyocytes. Eur J Pharmacol 532: 201-207, 2006.

7. Mazzio EA and Soliman KFA: Glioma cell antioxidant capacity relative to reactive oxygen species produced by dopamine. J Applied Toxicol 24: 99-106, 2004.

8. Shen JF, Wu YL, Xu JY, et al: ERK- and Akt-dependent neuroprotection by erythropoietin (EPO) against Glyoxal-AGEs via modulation of Bcl-xL, Bax, and BAD. Biochem Mol Biol 51: 2010.

9. Xu JD, Xilouri M, Bruban J, et al: Extracellular progranulin protects cortical neurons from toxic insults by activating survival signaling. Neurobiol Aging 32: 2326.e5-e16, 2011.

10. Nayak GH, Prentice HM and Milton SL: Neuroprotective signaling pathways are modulated by adenosine in the anoxia tolerant turtle. J Cerebral Blood Flow Metab 31: 467-475, 2011.

11. Aksamitiene E, Achanta S, Kolch W, Kholodenko BN, Hoek JB and Kiyatkin A: Prolactin-stimulated activation of ERK1/2 mitogen-activated protein kinases is controlled by PI3-kinase/ $\mathrm{Rac} / \mathrm{PAK}$ signaling pathway in breast cancer cells. Cell Signal 23: 1794-1805, 2011.

12. Luo DH and Fang BS: Structural identification of ginseng polysaccharides and testing of their antioxidant activities. Carbohyd Polym 72: 376-381, 2008.

13. CHOI KT: Botanical characteristics, pharmacological effects and medicinal components of Korean Panax ginseng CA Meyer. Acta Pharmacol Sin 29: 1109-1118, 2008.

14. Radad K, Gille G, Moldzio R, Saito H and Rausch WD: Ginsenosides Rb1 and Rg1 effects on mesencephalic dopaminergic cells stressed with glutamate. Brain Res 1021: 41-53, 2004.

15. Yuan QL, Yang CX, Xu P, et al: Neuroprotective effects of ginsenoside $\mathrm{Rb} 1$ on transient cerebral ischemia in rats. Brain Res 1167: 1-12, 2007.

16. Gerling N, Culmsee C, Klumpp S and Krieglstein J: The tyrosine phosphatase inhibitor orthovanadate mimics NGF-induced neuroprotective signaling in rat hippocampal neurons. Neurochem Int 44: 505-520, 2004.

17. Liao B, Newmark H and Zhou R: Neuroprotective effects of ginseng total saponin and ginsenosides Rb1 and Rg1 on spinal cord neurons in vitro. Exper Neurol 173: 224-234, 2002.

18. Radad K, Gille G, Moldzio R, Saito H, Ishige K and Rausch WD: Ginsenosides Rb1 and Rg1 effects on survival and neurite growth of MPP1-affected mesencephalic dopaminergic cells. J Neural Transm 111: 37-45, 2004.

19. Fan YY, Cheng HR, Liu D, et al: The inhibitory effect of ginseng pectin on L-929 cell migration. Arch Pharmacol Res 33: 681-689, 2010.

20. Fan YY, Cheng HR, Li SS, et al: Relationship of the inhibition of cell migration with the structure of ginseng pectic polysaccharides. Carbohyd Polym 81: 340-347, 2010.

21. Wang J, Li SS, Fan YY, et al: Anti-fatigue activity of the watersoluble polysaccharides isolated from Panax ginseng C.A. Meyer. J Ethnopharmacol 130: 421-423, 2010.

22. Cheng HR, Li SS, Fan YY, et al: Comparative studies of the antiproliferative effects of ginseng polysaccharides on HT-29 human colon cancer cells. Med Oncol 28: 175-181, 2010.

23. Zhang X, Yu L, Bi HT, et al: Total fractionation and characterization of the water-soluble polysaccharides is isolated from Panax ginseng C. A. Meyer. Carbohyd Polym 77: 544-552, 2009.

24. Kamada H, Nito C, Endo H and Chan PH: Bad as a converging signaling molecule between survival PI3-K/Akt and death JNK in neurons after transient focal cerebral ischemia in rats. J Cerebr Blood F Met 27: 521-533, 2007.

25. Xia Z, Dickens M, Raingeaud J, Davis RJ and Greenburg ME: Opposing effects of ERK and JNK-p38 MAP kinases on apoptosis. Science 270: 1326-1331, 1995. 